\title{
Adelograptus tenellus (Linnarsson 1871): its astogenetic development and its stratigraphical and palaeogeographical distribution
}

\author{
J. MALETZ \& B.-D. ERDTMANN
}

Maletz, J. \& Erdtmann, B.-D. Adelograptus tenellus (Linnarsson 1871): its astogenetic development and its stratigraphical and palaeogeographical distribution. Bull. geol. Soc. Denmark, vol. 35, pp. 179-190, Copenhagen, July 1st, 1987. https://doi.org/10.37570/bgsd-1986-35-19

\begin{abstract}
The graptolite fauna of the Tremadoc graptolite zone of Clonograptus tenellus from the typelocality at Nygård, Hunneberg, west-central Sweden, has been reinvestigated. Differences between the genera Adelograptus and Clonograptus are shown. Clonograptus tenellus is transferred to Adelograptus as $A$. tenellus with Clonograptus hians and Clonograptus sarmentosus treated as intraspecifical forms of younger (var. hians) or gerontomorphic (var. sarmentosus) growth stages. $A$. hunnebergensis as a laterally preserved younger form (compatible with var. hians) becomes a synonym of the older name $A$. tenellus. It may be concluded that the post-mortem orientation and mode of rhabdosome burial has a great influence on the taxonomic identification of graptolites. A short account on the palaeogeographic distribution and stratigraphic correlation follows.
\end{abstract}

J. Maletz \& B.-D. Erdtmann, Institut für Geologie und Paläontologie, Technische Universität Berlin, Hardenbergstrasse 42, D-1000 Berlin-12, Fed. Rep. Germany, October 4th, 1985.

\section{Introduction}

During geological field work on the Hunneberg Mountain in Västergötland, west-central Sweden, it became of interest to examine the Clonograptus and Adelograptus species originally described from the Clonograptus tenellus Zone of the Lower Tremadoc Dictyonema Shale from this area.

The graptolites, first described by Linnarsson (1871) from Nygård on the NW-slope of Hunneberg Mountain, were reported only to occur restricted to a single bedding plane in the lower part of a dark, pyrite-rich, possibly reworked shale layer. The thickness of these shales does not exceed $60 \mathrm{~cm}$ and yields graptolites only in a few places on the W-slope of the Mountain between Prästeklev in the South and Lugnet in the North. Only a few indeterminable graptolite fragments have been found in corresponding shale layers at Floklev on its E-slope. Discoveries of Rhabdinopora flabelliformis near Västra Tunhem and Holsbrottet confirm an assignment of this band of shales to the Tremadoc Dictyonema Shales. Below the layer with $A$. tenellus limestones occur belonging to the Upper Cambrian
Zone of Peltura scarabaeoides containing a great abundance of trilobites, especially of Sphaerophthalmus humilis (described as $S$. alatus by Linnarsson 1880). This was the reason for Linnarsson to include the shales with $A$. tenellus within the Upper Cambrian Olenus-beds. The upper boundary is placed at the base of limestones belonging to the Upper Tremadoc zone of Apatokephalus serratus.

\section{Systematic Palaeontology}

Order Dendroidea Nicholson 1872

Family Anisograptidae Bulman 1950

Subfamily Adelograptinae Mu 1974

Genus Adelograptus Bulman 1941

Type Species: Bryograptus ? hunnebergensis Moberg 1892 (= Dichograptus? tenellus Linnarsson 1871)

Diagnosis: Rhabdosome biradiate multiramous horizontal or declined, commonly somewhat lax and flexuous; branching principally dichotomous at mainly irregular and infrequent intervals; autothecae slender of moderate to low inclination and overlap; bithecae and sclerotized stolon system present; cortical overgrowth of proximal part of stipes (no webs!) in gerontic specimens.

Discussion: Until now several multiramous graptolites with sub-horizontal to declined rhabdosomes have been assigned to Adelograptus. Differences to the closely related Clonograptus could often only be seen in strictly horizontal rhabdosome of 
the latter and the more irregular branching type in Adelograptus. The proximal part of Clonograptus is symmetrical with both first order stipes consisting of one theca only, whereas in Adelograptus the length of the first order stipes is more variable and even both first order stipes may be of different length. Later dichotomies take place at greatly variable and irregular distances in both genera (Fig. 1).

Bithecae are present in Adelograptus, but have not been found in Clonograptus (see Braithwaite 1976, p. 15, Jackson 1973, p. 707). Only Erdtmann \& Gutierrez Marco (1987 in prep.) presume bithecae possibly present in early growth stages of $\mathrm{Clo}$ nograptus. But that has not as yet been proven as a thick cover of cortical overgrowth usually prevents a closer examination of thecal morphology in the proximal portion. A reduction in length of bithecae was noted by Stubblefield (1929) in stratigraphically younger forms of $C$. tenellus and $B$. hunnebergensis in the Transition-beds of Shropshire.

Clonograptus was formerly included with the Anisograptidae (Bulman 1970) mainly due to consideration given to the dendroid (bithecate) development of Clonograptus tenellus. We include here Clonograptus within the graptoloid family Dichograptidae and retain Adelograptus as the bithecae-bearing ancestor in the dendroid Anisograptidae.

The revised classification of the Anisograptidae proposed in Lin (1981) and mainly based upon the number of first order stipes, would appear questionable as some species, for example Psigraptus jacksoni with three to four presumed primary stipes (Rickards \& Stait 1984) or Kiaerograptus?quasimodo with two to three presumed primary stipes (Rushton 1981), possess considerable variability in the number of first order stipes. Lin (1981) included the genus Clonograptus within the Adelograptinae and divided this genus into the tenellus-group and the flexilis-group, a splitting now superfluous when including the fenellus-group of dendroid development within Adelograptus.

The stratigraphical distinction of both genera is also significant.

The more primitive dendroid Adelograptus is found in the Tremadoc, whereas the more advanced graptoloid Clonograptus appears first near or above the upper boundary of the Tremadoc Series and the Scandinavian Hunneberg Substage (? lower Arenig).

Adelograptus tenellus (Linnarsson)

Plate 1, Figs. A-C, Plate 2, Figs. A-M

1871 Dichograptus ? tenellus n. sp. - Linnarsson: p. 794, pl. 16, figs. 13-15

non 1880 Bryograptus callavei n. sp. - Lapworth (a): p. 165 , pl. 5 , figs. $21 \mathrm{a}, \mathrm{b}$

1892 Clonograptus tenellus var. hians n. var. - Moberg: $\mathrm{p}$. 92, fig. 4

1892 Bryograptus ? hunnebergensis n. sp. - Moberg: p. 92 , pl. 1, figs. 5-7, ?8,9

1892 Bryograptus ? sarmentosus n. sp. - Moberg: p. 95, pl. 1 , figs. $10-12$

1892 Clonograptus tenellus (Linnarsson) - Moberg: p. 89, pl. 1, figs. 1-3, ?4

1902 Clonograptus tenellus var. callavei (Lapworth) Elles \& Wood: p. 84, pl. 11, figs. 3a-c, textfig. 47

1906 Clonograptus tenellus (Linnarsson) forma typica Moberg \& Segerberg: p. 60 , pl. 1, fig. 8

1906 Clonograptus tenellus var. hians (Moberg) - Moberg \& Segerberg: p. 61, pl. 1, fig. 11

1906 Clonograptus tenellus var. callavei Lapworth (Elles \& Wood) - Moberg \& Segerberg: p. 60, pl. 1, figs. 9,10

1909 Bryograptus hunnebergensis Moberg - Westergård: p. 64 , pl. 5, figs. $10-20,23, ? 21,22$

1909 Clonograptus tenellus var. hians Moberg - Westergård: p. 69 , pl. 4 , figs. 27,28

1909 Clonograptus tenellus (Linnarsson) forma typica -
Westergård: p. 68 , pl. 4 , figs. $14-26,29$, pl. 5 , figs. 1a,b

1909 Clonograptus tenellus var. callavei (Lapworth) Westergård: p. 69 , pl. 4 , figs. 1-13, pl. 5 , fig. 2

1909 Clonograptus tenellus var. grandis n. var. - Westergård: p. 69 , pl. 5 , figs. 3a,b, ?4-6

1929 Bryograptus hunnebergensis Mober \& Stubblefield: p. 273 , figs. $2-7$

1929 Clonograptus tenellus (Linnarsson) - Stubblefield: p. 278 , figs. $1,8-11$

1929 Clonograptus tenellus var. callavei Elles \& Wood Stubblefield: p. 282

1949 Adelograptus hunnebergensis (Moberg) - Bulman: p. 40 , fig. 5

1974 Adelograptus hunnebergensis (Moberg) - Hutt: p. 79-92, figs.

1974 Clonograptus tenellus (Linnarsson) - Hutt: p. 79, figs.

A type specimen has never been defined. Linnatsson's original material of Dichograptus? tenellus from Nygård, Hunneberg, could not be traced and consists only of fragments as seen on his figures (Linnarsson 1871, pl. 16, figs. 13-15).

A neotype has been selected from material collected at the same horizon at Nygård, Skaktet No. 1 by Von Schmalensee and described by Moberg (1892). It is kept at the Sveriges Geologiska Undersökning (SGU), Uppsala, and bears the No. SGU 4497. This specimen is fairly complete with stipes developed up to the 5th order and was originally described and figured by Moberg (1892, figs. 1a,b).

Material: Several specimens collected by Von Schamalensee at Nygård, along with additional material from Nygård and Holsbrottet, NW-slope of Hunneberg Mountain collected by Maletz in 1985.

Description: Rhabdosome biradiate multiramous, up to 6 th or 7 th order delayed bifurcations. Mature specimens reach a diameter of more than $10 \mathrm{~cm}$. The sicula, when seen in laterally preserved specimens, measures $1.0-1.2 \mathrm{~mm}$ in length and possesses a long slender nema. For details see Hutt (1974) who prepared an excellent description of the development of the early growth stages. The proximal development is of isograptid-type, the second theca, th $1^{2}$, being the dicalycal theca. As in only few other forms the development mode appears to be arbitrarily sinistral or dextral (Stubblefield 1929, Hutt 1974). Each first order stipe consists of two or three thecae, or seldom only of one, showing a dicalycal theca with no fixed place, as in typical Anisograptids. Younger specimens (var. hians) show first order stipes including an angle of about $110-150^{\circ}$, in the more mature rhabdosomes (var, typica) they form a straight line, attaining a length of the funicle of about $3-6 \mathrm{~mm}$. The higher order dichotomies are usually progressively delayed with the stipes of the same order being of subequal length, demonstrating a more or less regular appearance. In the younger forms, when the stipes of the proximal parts have not been coated with corti cal tissues, the whole rhabdosome appears to be slender and flexuous. The width of the stipes reaches only $0.25-0.40 \mathrm{~mm}$ dorso-ventrally and $0.50 \mathrm{~mm}$ laterally. As suggested by Owens et al. $(1982$, p. 17) in mature forms the proximal parts are progressively coated with cortical overgrowth and lose their flexibility, the terminal stipes attain a subparallel orientation. The thecae of the proximal parts disappear under the secondary overgrowth and in extremely large specimens the rhabdosome shows a tapering width of stipes. The thecae are straight and slender with a length of about $1.5 \mathrm{~mm}$, overlapping about $1 / 3$ of their length. For details of thecae and branching mode see Hutt (1974, p. 87), who mentioned spined thecae as a gerontic feature, seen only on specimens thickly covered with cortical tissues. 


\section{Clonograptus sp.}
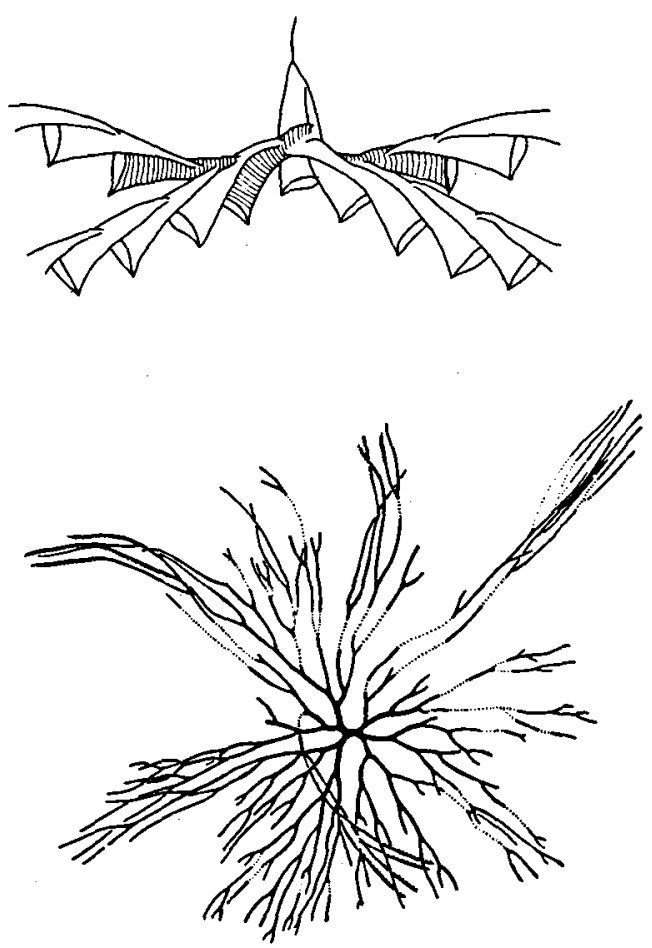

Adelograptus sp.


Figur 1. Comparison of Clonograptus sp. and Adelograptus sp. Dicalycal thecae are striped, bithecae are stippled. Proximal part of Clonograptus sp. reconstructed (data obtained from personal collections). Proximal part of Adelograptus sp. (= A. tenellus) from Hutt (1974) with personal additions. mature specimens from Bulman (1970, V40, fig. 18-1a) and Moberg (1892, fig. 1a).

Discussion: The variability of stipe length in $A$. tenellus is shown on Table 1 . The measurements are mainly from specimens associated with Moberg's types. They show considerable variation in stipe length of all orders including the funicle. Broken distal stipes associated with the material (PI. 2M), measure more than $25 \mathrm{~mm}$. Specimens reaching more than 5 orders of stipes are not known from the type locality at Hunneberg, but have been found in material from the Carmarthen district (Cope et al. 1978, pl. 1b).

Judging by the measurements var. hians appears to lie within the range of $A$. tenellus and could be taken to be a variety with relatively long second order stipes and showing slender dorsoventrally preserved rhabdosomes. Differences in the angle of divergence between stipes are not taken for discrimination of

Table 1. Biometric data of Adelograptus tenellus, mainly obtained from type material and specimens associated with the types.

\begin{tabular}{|c|c|c|c|c|c|c|c|c|c|}
\hline \multirow[b]{2}{*}{ Species } & \multirow{2}{*}{$\begin{array}{l}\text { length of } \\
\text { Sicula }\end{array}$} & \multirow[b]{2}{*}{ funicle } & \multicolumn{3}{|c|}{ length of stipes } & \multirow[b]{2}{*}{ 5th ord. } & \multicolumn{2}{|c|}{ stipe width } & \multirow{2}{*}{$\begin{array}{c}\text { thecae in } \\
10 \mathrm{~mm}\end{array}$} \\
\hline & & & 2nd ord. & 3rd ord. & 4th ord. & & lateral & $\begin{array}{l}\text { dorso- } \\
\text { ventral }\end{array}$ & \\
\hline A. tenellus & $\begin{array}{c}1.0-1.2 \\
\mathrm{~mm}\end{array}$ & $\begin{array}{c}3.0-6.0 \\
\mathrm{~mm}\end{array}$ & $\begin{array}{c}3.0-12.0 \\
\mathrm{~mm}\end{array}$ & $\begin{array}{c}5.0-10.0 \\
\mathrm{~mm}\end{array}$ & $\begin{array}{c}7.0-12.0 \\
\mathrm{~mm}\end{array}$ & $\begin{array}{c}\text { more than } \\
15.0 \mathrm{~mm}\end{array}$ & $\begin{array}{l}0.5 \\
\mathrm{~mm}\end{array}$ & $\begin{array}{c}0.3-0.5 \\
\mathrm{~mm}\end{array}$ & 10 \\
\hline A. hunnebergensis & $\begin{array}{l}1.2 \\
\mathrm{~mm}\end{array}$ & $\begin{array}{c}3.5-4.0 \\
\mathrm{~mm}\end{array}$ & $\begin{array}{c}4.0-7.0 \\
\mathrm{~mm}\end{array}$ & $\begin{array}{l}\text { more than } \\
8.0 \mathrm{~mm}\end{array}$ & - & - & $\begin{array}{l}0.5 \\
\mathrm{~mm}\end{array}$ & $\begin{array}{c}0.25-0.4 \\
\mathrm{~mm}\end{array}$ & 10 \\
\hline $\begin{array}{l}\text { A. tenellus var. } \\
\text { hians }\end{array}$ & - & $3.5 \mathrm{~mm}$ & $\begin{array}{c}5.5-8.0 \\
\mathrm{~mm}\end{array}$ & $\begin{array}{c}\text { more than } \\
8.0 \mathrm{~mm}\end{array}$ & - & - & $\begin{array}{c}0.25-0.3 \\
\mathrm{~mm}\end{array}$ & - & - \\
\hline $\begin{array}{l}\text { A. tenellus var. } \\
\text { grandis }\end{array}$ & - & $\begin{array}{c}4.0-6.0 \\
\mathrm{~mm}\end{array}$ & $\begin{array}{l}7.0 \text { and } \\
\text { more }\end{array}$ & $\begin{array}{l}12.0 \text { and } \\
\text { more }\end{array}$ & $\begin{array}{l}13 \mathrm{~mm} \text { and } \\
\text { more }\end{array}$ & - & $\begin{array}{l}0.75 \\
\mathrm{~mm}\end{array}$ & - & 9.10 \\
\hline
\end{tabular}


these forms. The material indicates greatly flexible stipes in which the angles could easily be altered. The types of $B$. hunnebergensis consists merely of a few small specimens with stipes developed as far as the third order. Therefore, little variation could be found. More variable specimens were illustrated by Westergård (1909, pl. 5, figs. 10-23), these also show only three orders of stipes. Two of Moberg's specimens were more horizontally preserved (Pl. 2E, G) and could not be distinguished from smaller specimens of $A$. tenellus.

$C$. tenellus var grandis does show extremely long distances between bifurcations, but in all other aspects it fits in with $A$. tenellus. This form has not been found together with $A$. tenellus at Hunneberg. B.?sarmentosus is a form with relatively short distances between its dichotomies and has a strong development of cortical overgrowth. No thecal details are known. The types consists of two fragments without proximal parts. In comparison to other multiramous graptolites like $C$. rigidus and $C$. flexilis, being sometimes also heavily cortex-enveloped, it would seem reasonable to interprete this form as a gerontic variety of $A$. tenellus.

\section{Biostratinomy and hydrodynamics of graptolite burial}

The post-mortem orientation and mode of rhabdosome burial has a great influence on the taxo- nomic identification of graptolites. For a long time little attention has been paid to this fact. The first to suggest that different graptolites could probably be only alternative forms due to an effect of preservation, was Westergård (1909, p. 64). He stated that some forms of Bryograptus and Clonograptus are related so closely that the mode of preservation would be the only reason to include them either with the former or with the latter genus, taking as example $C$. tenellus var. hians as horizontally preserved form and $B$. hunnebergensis as the laterally preserved corresponding form. This idea is also supported by the similarities in the proximal part of both (Hutt 1974) and the high variance of stipe length. Characteristic for $A$. hunnebergensis is a moderately declined to almost horizontal mainly lax and flexible rhabdosome which allows early growth stages to be preserved either in horizontal or in lateral orientations. The type specimens (pl. 2A,B,D) show the lateral mode of preservation. A more

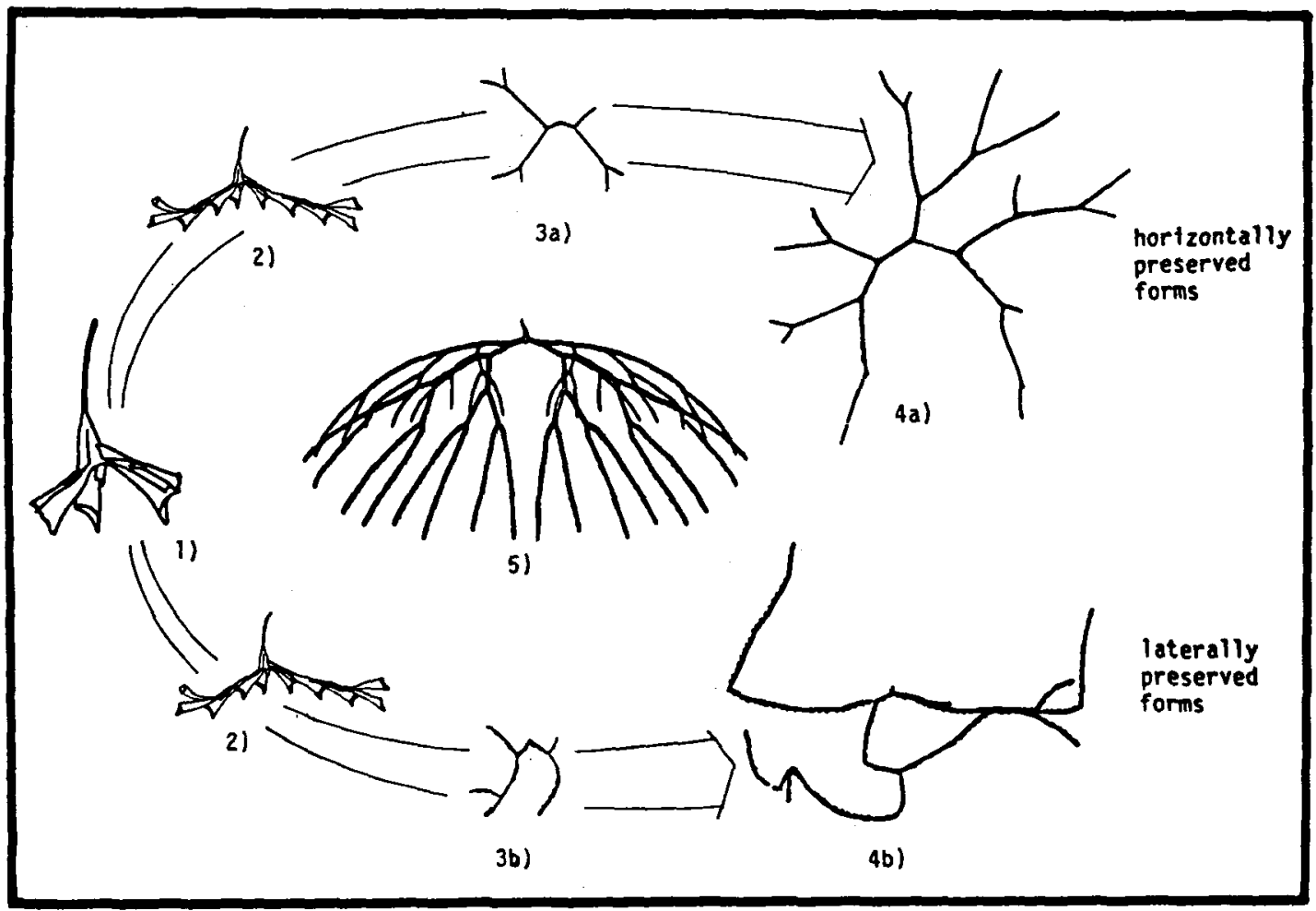

Figur 2. The astogenetic development and mode of preservation in Adelograptus tenellus. 1,2: juvenile form (no horizontal preservation observed), 3: slightly older form with stipes until the 3rd order, 3a: figured by Moberg (1892) as $C$. tenellus var. hians, 3b: figured by Moberg (1892) as ?Bryograptus hunnebergensis, 4: mature form, 4a: figured by Moberg (1892) as Clonograptus tenellus, 4b: figured by Stubblefield (1929) as Bryograptus hunnebergensis, 5: reconstructed three-dimensional specimen (Figures not to scale). 
horizontal preservation is indicated by two other specimens (PI. 2E,G) only provisionally included in B.?hunnebergensis by Moberg (1892). Both aspects of preservation in the genus Adelograptus were also demonstrated by Cooper (1979, fig. 19) for Adelograptus clarki. (Fig. 2)

In the more horizontally growing species of Clonograptus the mode of preservation appears only to be horizontal, being affected by the more rigid nature of the whole rhabdosome, such as the heavily cortex-enveloped forms seen in $C$. rigidus and $C$. flexilis. A lateral preservation would appear possible only before development of second order stipes.

The biostratinomic emplacement of graptolite rhabdosomes on the burial substrate is affected mainly by two factors: by the physical-chemical condition of the water mass and by the developmental stage (astogeny) of the rhabdosome and its specific hydrodynamic behaviour.

In stagnant water the more or less horizontally to slightly cone-shaped rhabdosomes (in life-position) of multiramous graptolites are emplaced on the bedding planes with all branches spread out horizontally. It has never been observed that the rhabdosomes penetrate into the anoxic mud on the sea bottom. All rigidly interconnected branches are in the same dorso-ventral state of preservation. Only distal stipe ends may be slightly twisted into hydrodynamically stable position (profile view) due to the flexibility of their organic skeleton, but they are usually not broken.

In contrast to this preservation current-sorted rhabdosomes are often broken or distorted and thus represent fragmentary specimens. This is most evident for the larger rhabdosomes of all multiramous graptolites. Therefore, when mature specimens are preserved in lateral preservation they are always fragmentary and do not show the complete number of stipes. Reference may be given to such preservational state of the large specimen of $A$. hunnebergensis illustrated by Stubblefield (1929, fig. 7) to serve as an example. This specimen represents also the only specimen of this species with more than three orders of stipes being developed.

The growth orientations distinct of astogenetic stages of younger specimens relative to their preservation are more complicated. This is illustrated in fig. 3. The figure shows a hypothetical multiramous graptolite in which the three axes of the rhabdosome are indicated by the letters A, B and $C$. In a horizontally extended multiramous graptolite there are two directions in which the rhabdosome grows: these are the axes $\mathrm{A}$ and $\mathrm{B}$. Axis $C$ in this case remains constant in length and is represented by the sicular individual only. The axes $A$ and $B$ represent the planes in which the stipes grow.

From this model it is evident that the mode of preservation depends strongly upon the developmental stage of the graptolite, meaning the number and length of stipes.

Every graptolite will be placed hydrodynamically on the bedding plane with the two longest axes being spread out horizontally. A sicular individual which possesses only one long axis, (fig. $3 a$ ), being the $\mathrm{C}$ axis, (both $\mathrm{A}$ and $\mathrm{B}$ axes are equal in length and much shorter than the $C$ axis), is always preserved laterally with the longest axis lying along in the bedding plane.

In slightly later astogenetic stages, with the development of first order stipes, the $A$ axis is growing to greater length, whereas the $B$ and $C$ axes remain constant in length. In this case the $B$ axis becomes the shortest axis and a preservation is only possible laterally with the $B$ axis perpendicular to the bedding plane (fig. $3 b$ ).

In the next astogenetic stage, after development of second order stipes, the mode of preservation changes from lateral to horizontal, due to the expanded growth of the rhabdosome along the $B$ axis. The $C$ axis, being the longest one in the sicular individual, becomes now the shortest axis of the rhabdosome and has no longer any influence on the preservation of the graptolite. Therefore all mature astogenetic stages would be preserved essentially in horizontal mode (fig. 3c).

Both factors of preservation are also affected by yet another characteristic of the graptolite rhabdosome: Graptolites possess exclusively nonmineralized skeletons, which are by their hair-like nature more or less flexible. Therefore current-sorted rhabdosomes could be preserved in highly variable configurations because of the high degree of flexibility of their eviscerated skeletons. The robust and more rigid mature clonograptids and temnograptids are known to be preserved only in horizontal orientation. Because of the rigidity of their proximal parts a lateral preservation is practically impossible. On the 

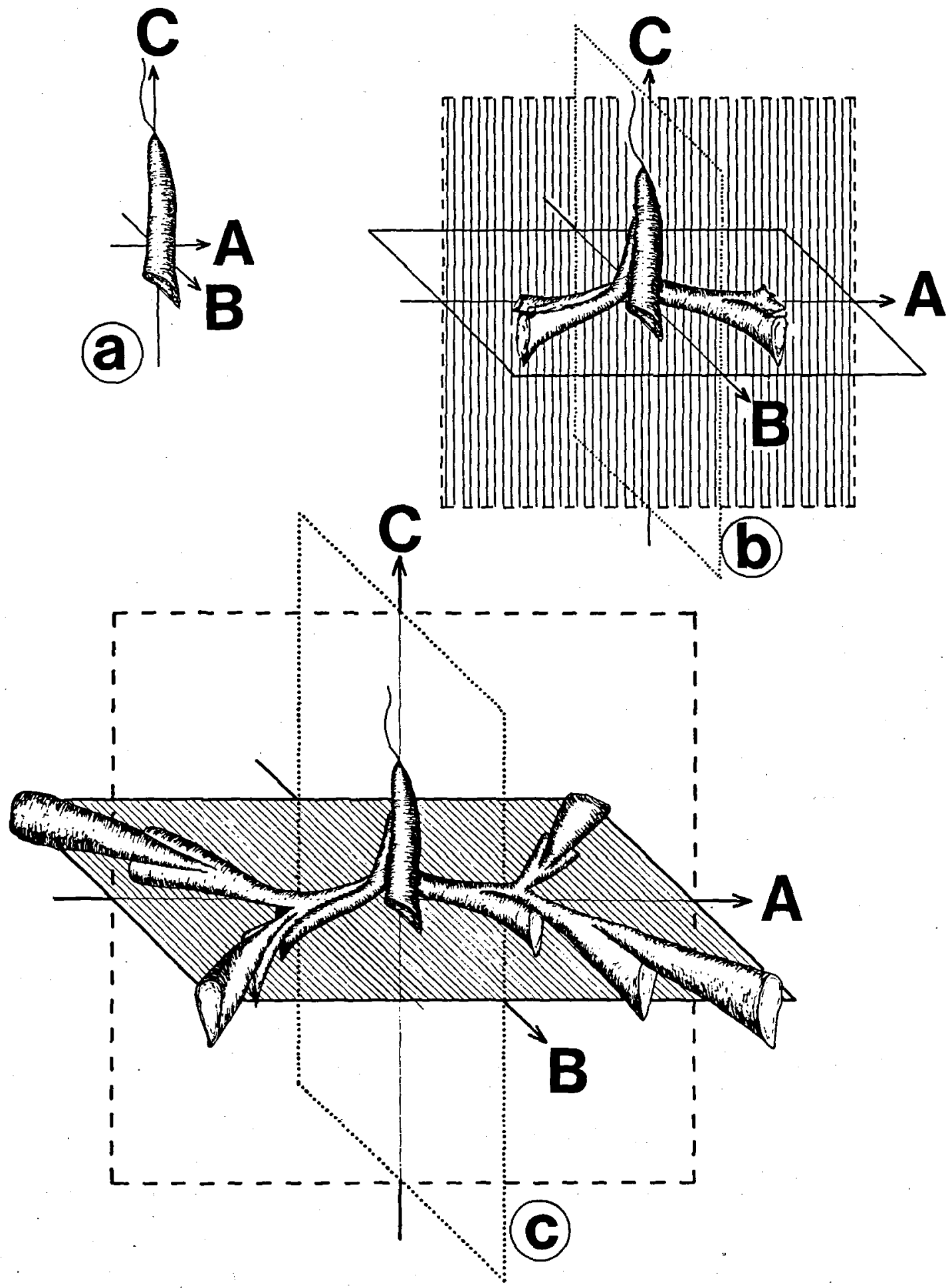

Figur 3. Diagram illustrating hydrodynamics of graptolite burial. a: sicular individual, b: specimen with horizontally extended first order stipes, c: specimen with second or higher orders stipes extending in a plane defined by axes A and B (perpendicular to sicula). Shaded areas represent burial plane (or burial axis in a). 




Table 2. Comparison of Tremadocian graptolite zones from Scandinavia and Great Britain.

other hand, the slender mature anisograptids and delicate adelograptids are sometimes also laterally preserved. Among these more delicate rhabdosomes, especially when affected by current emplacement all preservational stages from strictly horizontal to clearly lateral modes could be observed.

Until now the taxonomic status of $C$. tenellus and its varieties were confusing, as shown by several authors who were unable to distinguish between them (see note in Hutt, 1974, p. 80). Our work suggests to remove $C$. tenellus from the clonograptids and to include it with Adelograptus as $A$. tenellus with var. hians and var. sarmentosus treated as intraspecifical forms of early (var. hians) or gerontomorphic (var. sarmentosus) growth stages. C. tenellus var grandis is a form with extremely long distances between bifurca- tions, but there are nor reasons for taking this form as being more than a variety. A. hunnebergensis, as a laterally preserved younger form (compatible with var. hians) is a junior synonym of the older $A$. tenellus.

\section{Palaeogeographic distribution and stratigraphic correlation}

The geographic distribution of A. tenellus seems to be restricted to Great Britain, southern Scandinavia, the Baltic area and possibly North Africa (see also Bulman 1971, 55-56) (table 2).

In southern Scandinavia $A$. tenellus is widely distributed in the upper part of the Lower Tremadoc. The species occurs mainly without associated faunal elements in the upper part of the 
Dictyonema Shales of Bornholm (Poulsen 1922), Scania (Moberg \& Segerberg 1906, Westergård 1909), Öland (Westergård 1922, 1944), Västergötland (Linnarsson 1871, Thorslund 1937), Östergötland (Westergård 1909), and possibly of the Oslo region (Monsen 1925, Bulman 1954, Erdtmann 1965) and is followed by shales with Rhabdinopora flabelliformis var. norvegica (Hede 1951, Tjernvik 1958). This shows clearly that the zone of $A$. tenellus has to be placed within the Dictyonema Shales, between the zones of $R$. $f$. flabelliformis and $R$. $f$. var. norvegica. A similar stratigraphic occurrence is assumed in borings in Great Britain (Bulman \& Rushton 1973) and also from several outcrops (Nicholas 1915, Stubblefield \& Bulman 1927, Curtis 1968, Cope et al. 1978, Owens et al. 1982).

Records from the Russian Platform are only very few and do not give convincing evidence as to the distribution eastwards. Information is published from the Baltic republics (Ulst 1976, Kaljo \& Kivimägi 1976, Kaljo 1985 personal communication) and from the Gorny Alti in Siberia (Obut \& Sennikov 1984).

Little information also exists from North Africa, from Algeria (Legrand 1960) and Morocco (Destombes 1960, Destombes et al. 1969) of forms only doubtfully referred to $A$. tenellus until better preserved material would confirm the correct identifications.

From Australasia the first observation of this species was made by Hall (1899) who described C. rigidus var. tenellus from the Lancefield beds of Victoria. He mentioned a large number of intermediate examples between $C$. tenellus and $C$. rigidus and united them to one species. Since that time $C$. tenellus has been recorded infrequently form the Lancefield beds of Australia and New Zealand. B. hunnebergensis was recorded from New Zealand by Benson \& Keble (1935) together with $C$. tenellus var. kingi, a newly described variety, later treated as $C$. kingi by Bulman (1941). Another new form was introduced by Harris \& Thomas (1938). This was $C$. tenellus var. problematica from the Be 1 of Campbelltown, Victoria. In this form the development of the rhabdosome shows a possible close relation to forms like Clonograptus herrmanni (Monsen 1937) and Clonograptus subtilis (Törnquist 1904) from Scandinavia and the form should provisionally be included in Clonograptus as $C$. problematic $a$ until a better understanding could clear up the taxonomic status of these forms.

Bulman (1941) and Bulman \& Cooper (1969) proposed that $C$. tenellus and $A$. hunnebergensis reported from the La 2 of New Zealand were incorrect identifications. The same may be true for forms from the La 2 of Australia. A stratigraphical correlation shows no evidence for the existence of $A$. tenellus in Australia, because the Australian La 2 fauna could be correlated with the Hunnebergian (? lower Arenig) zone of Adelograptus? antiquus and Clonograptus norvegicus recently under investigation by the authors at the Hunneberg in Västergötland.

From China only a few reports have been made. Hsü (1936) mentioned C. tenellus var. callavei together with the trilobite Asaphus ovatus from the Tanchiachiao Shale of South Anhui. The same species was also reported by Mu (1955) from the Yinchupu Shale of western Chekiang (Zheijiang) together with several other graptolites (Anisograptus cf. matanensis var. tetragraptoides, Adelograptus asiaticus) in the Clonograptus-Triarthrus Zone. In a "Handbook of Palaeontology of Central-South China" Wang \& Fu (1977) described Clonograptus tenellus zhonguoensis from the Lower Ordovician Fenxiang Formation of Hunan, a horizontally preserved form with a more or less regular appearance of the rhabdosome. Also the presence of bithecae gives evidence in support of an inclusion of this form with Adelograptus as $A$. zhonguoensis. The stratigraphical assignment is difficult to ascertain. The associated faunas show only a possible correlation with the Upper Tremadoc.

Braithwaite (1976) described C. sarmentosus from the lower part of the Fillmore Limestone of the Pogonip Group, Utah. This form occurs together with Adelograptus elegans in Zone 2 of the lower Arenig and is only questionably referred to A. tenellus, from which it differs in the short funicle and closer spaced dichotomies. Braithwaite stated that the biostratigraphic correlation is 


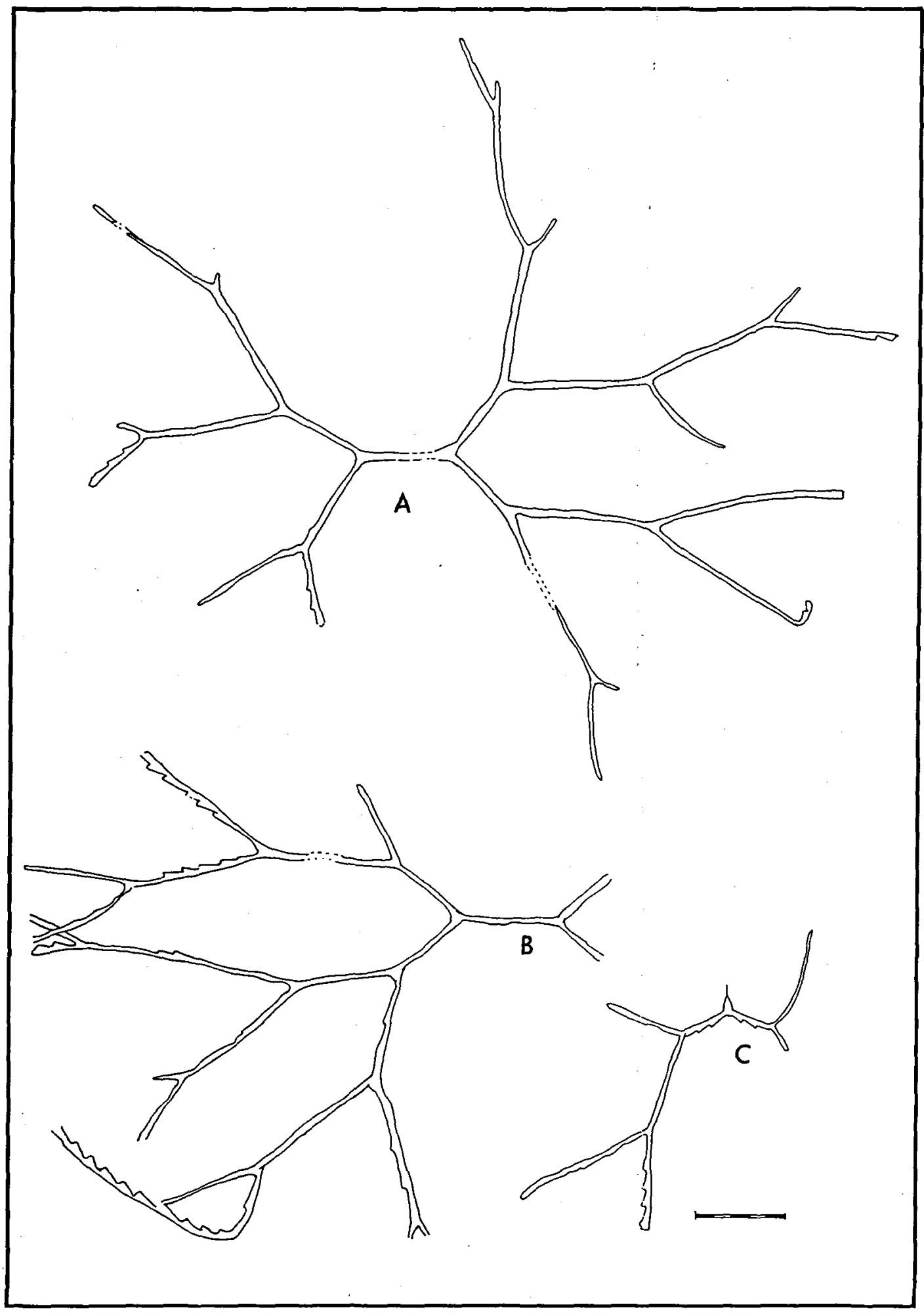




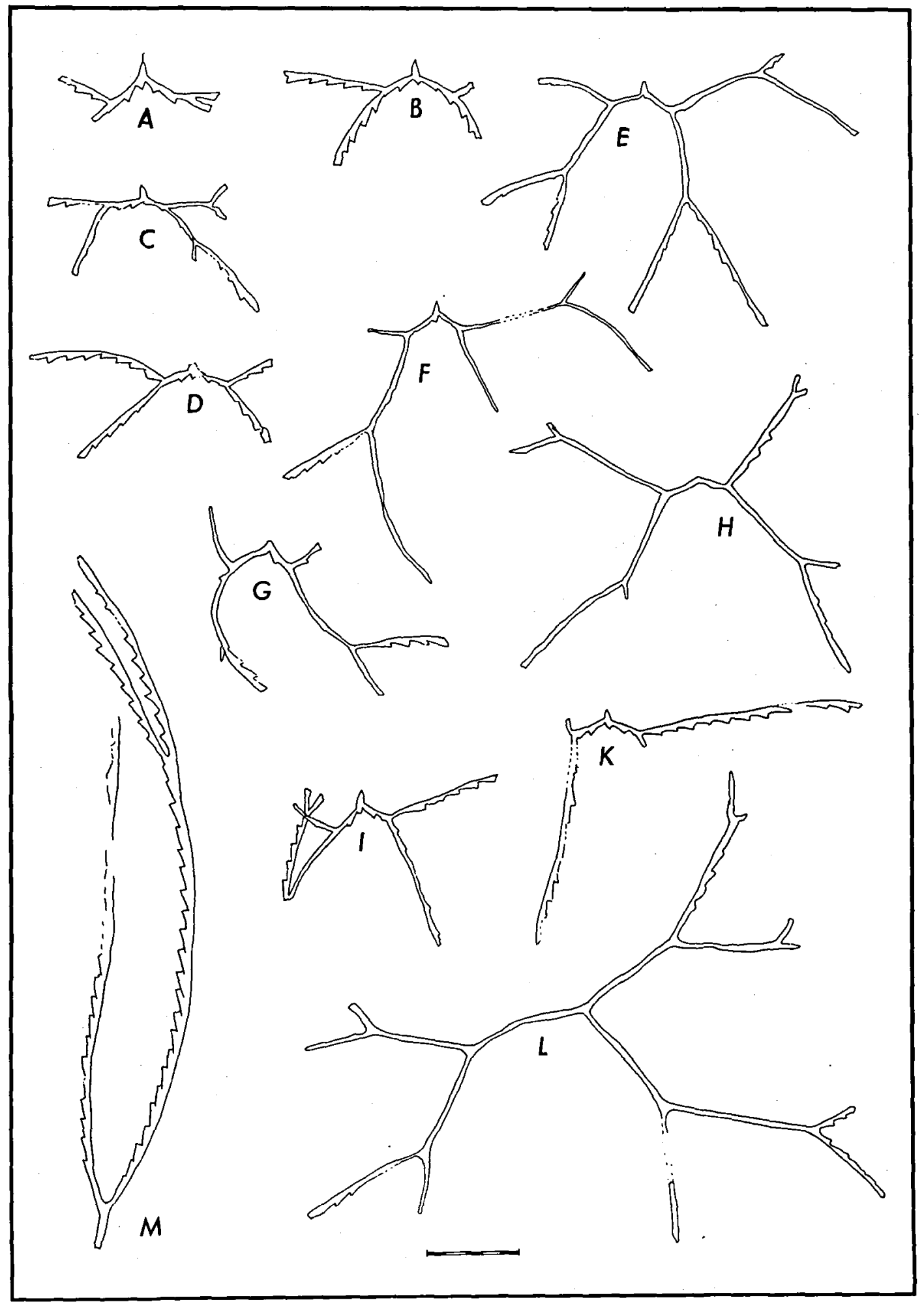


doubtful but correlated his Zone 2 with the Adelograptus-Clonograptus Zone of Texas.

The Texas specimens of $C$. cf. tenellus described by Berry (1960) are very slender forms with a relatively regular appearance and very short first order stipes. Bithecae are not mentioned. The fauna with Anisograptus dissolutus and $C$. cf. tenellus (Zone 1) shows a possible relation to the Upper Tremadoc.

From the Road River Formation of Yukon (Jackson \& Lenz 1962, Lenz \& Pedder 1972) C. tenellus has been reported together with Staurograptus dichotomus and Anisograptus spp. in the Staurograptus Zone of the Lower Tremadoc, but the form has never been described or figured, and subsequently described Clonograptus aureus (Jackson 1973) is with certainty a real Clonograptus species from the Upper Tremadoc.

Records of $C$. sarmentosus from Quebec (Erdtmann 1967) are certainly a misidentification. The form shows a very short funicle and a strong development of cortical tissues in the proximal parts and seems therefore being more closely related to $C$. norvegicus. A. hunnebergensis from Martin Point, Newfoundland (Erdtmann $1971 \mathrm{a}, \mathrm{b}$ ) in association with $C$. rigidus, $C$. flexilis, Tetragraptus cf. $T$. decipiens, $T$. acclinans and Bryograptus spp. in Zone 2 shows possibly a stratigraphically younger Adelograptus species. Until now the occurrence of $A$. tenellus in Newfoundland is unclear. Finally the reported occurrence (Poulsen 1937) of $C$. tenellus from East Greenland is based on fragmentary material that cannot be assigned to $A$. tenellus.

Acknowledgements. The authors want to thank Y. Grahn (Uppsala) and K. Lindholm (Lund) for making the type-material available. Additional informations were presented by $\mathbf{R}$. Fortey (Great Britain), J. Hutt (Great Britain), D. Kaljo (Tallinn), Lin Yao-kun (Nanjing) and Wang Xiao-feng (Yichang).

\section{Dansk sammendrag}

Der er blevet foretaget et fornyet studie af graptolitfaunaen fra Clonograptus tenellus zonen fra typelokaliteten Nygård ved Hunneberg i Sverige. Den er af tremadoc alder. Der påvises forskelle mellem Adelograptis og Clonograptus. Clonograptus tenellus henfores til Adelograptus, mens Clonograptus hians og C. sarmentosus betragtes som intraspecifiske former, idet varieteten hians regnes for et ungdomsstadie og sarmentosus som et alderdomsstadie. $A$. hunnebergensis er et juniorsynonym af $A$. tenellus. Det konkluderes at transport af rhabdosomer og indlejringsforløbet i sedimentet har stor taxonomisk indflydelse på identifikationen af de relevante former. Der gives en kort oversigt over den paleogeografiske og stratigrafiske fordeling og korrelation af de relevante former.

\section{References}

Benson, W. N. \& Keble, R. A. 1935: The Geology of the Regions Adjacent to Preservation and Chalky Inlets, Fjordland, New Zealand, Part 4, Stratigraphy and Palaeontology of the Fossiliferous Ordovician Rocks. Trans. $R$. Soc. N. Z. 65, 244-294.

Berry, W. B. N. 1960: Graptolite faunas of the Marathon Region, West Texas. Univ. Texas Publ. 6005, 1-179.

Braithwaite, L. F. 1976: Graptolites from the Lower Ordovician Pogonip Group of Western Utah. Geol. Soc. Am., Special Paper 166, 1-106.

Bulman, O. M. B. 1941: Some dichograptids of the Tremadocian and Lower Ordovician Ann. Mag. Nat. Hist., Ser. $11,7,100-121$.

Bulman, O. M. B. 1949: A re-interpretation of the structure of Dictyonema flabelliforme Eichwald Geol. Fören. Förhandl. $71,33-40$.

Bulman, O. M. B. (1950): Graptolites from the Dictyonema Shales of Quebec. Quart. J. Geol. Soc. London 106, 63-99.

Bulman, O. M. B. 1954: The Graptolite Fauna of the Dictyonema Shales of the Oslo Region. Norsk Geol. Tidsskr. $33,1-40$.

Bulman, O. M. B. 1970: In: Teichert, C. (ed.): Treatise on Invertebrate Palaeontology V, Graptolithina with sections on Enteropneusta and Pterobranchia, (2nd Edition), IXXXII, 163 pp. - Geol. Soc. Am. and Univ. Kansas.

Bulman, O. M. B. (1971): Graptolite faunal distribution. In: Middlemiss, F. A., Rawson, P. F. \& Newall, P. F. (eds.): Faunal Provinces in Space and Time. - Geol. J. Spec. Issue, 4, 47-60.

Bulman, O. M. B. \& Cooper, R. A. 1969: On the supposed Occurrence of Triograptus in New Zealand. Trans. R. Soc. N. Z. Geology 6 (16), 213-218.

Bulman, O. M. B. \& Rushton, A. W. A. 1973: Tremadoc Faunas from Boreholes in Central England. Bull. Geol. Surv. Gt. Br. 43, 1-40.

Cooper, R. A. 1979: Ordovician Geology and Graptolite Faunas of the Aorangi Mine Area, Northwest Nelson, New Zealand. Pal. Bull. N. Z. Geol. Surv. 47, 127 pp.

Cope, J. C. W., Fortey, R. A. \& Owens, R. M. 1978: Newly discovered Tremadoc rocks in the Carmarthen district, South Wales. Geol. Mag. 115, 195-198.

Curtis, M. L. 1968: The Tremadoc rocks of the Tortworth Inlier, Gloucestershire. Proc. Geol. Ass. 79, 349-362.

Destombes, J. 1960: Sur L'extension du Tremadoc dans le Sud marocain. Comptes rendus des seances mensuelles de la So-

Plate 2. Adelograptus tenellus (Linnarsson 1871), A: SGUं 4505, B: SGU 4506, C: laterally preserveo specimen with 3rd order stipes, D: SGU 4504, E: SGU 4499b, F: fragmentary specimen showing 3rd order stipes, G: SGU 4501b, H: dorso-ventrally preserved younger specimen, I, K: specimens with extremely long second order stipes, L: SGU 4500b, M: SGU 4498a, specimens A,B,D are the types of Bryograptus?hunnebergensis figured first by Moberg (1892), specimens $\mathrm{E}, \mathrm{G}$ only tentatively assigned to B.?hunnebergensis by Moberg (1892), specimens L,M figured as Clonograptus tenellus by Moberg (1892), all other specimens are found together with neotype of a. tenellus (SGU 4497) on one slab, Bar indicates $5 \mathrm{~mm}$. 
ciete des Sciences naturelles et physics du Maroc 26, 3 , 45-47.

Destombes, J., Sougy, J. \& Willefert, S. 1969: Revision et decouvertes paleontologiques (Brachiopodes, Trilobites et Graptolites) dans le Cambro-Ordovicien du Zemmour (Mauretanie septentrionale). Bull. Soc. geol. France (7), XI, 185-206.

Elles, G. L. \& Wood, E. M. R. 1902: A Monograph of British Graptolites, Part II, Palaeont. Soc. Lond. 56, No. 265.

Erdtmann, B.-D. 1965: Eine spät-tremadocische Graptolitenfauna von Töyen in Oslo. Norsk Geol. Tidsskr. 45, 97-112.

Erdtmann, B.-D. 1967: A new fauna of Early Ordovician graptolites from St. Michel, Quebec. Can. Journ. Earth Sc. 4, 335-355.

Erdtmann, B.-D. 1971a: Tetragraptus otagoensis and Janograptus terranovensis n. sp., Ordovician Graptolites from Western and Northern Newfoundland Journ. Pal. 45, No. 2, 258-264.

Erdtmann, B.-D. 1971b: Ordovician Graptolite Zones of Western Newfoundland in Correlation to Palaeontology of the North Atlantic. Bull. Geol. Soc. Am. 82, 1509-1528.

Erdtmann, B.-D. \& Gutierrez Marco, J. C. 1986 (in prep.): Graptolite Fauna, Ecostratigraphy and Palaeoenvironment of Early Ordovician (Transition Tremadoc-Arenig or La2 Be2, Hunneberg Stage) Barriga Shales, Venta del Ciervo, Ossa-Morena Zone, SW Spain.

Hall, T. S. 1899: Victorian Graptolites, Part 2, The Graptolites of the Lancefield beds. Proc R. Soc. Vict. 11 (N.S.), 164 178.

Harris, W. J. \& Thomas, D. E. 1938: Victorian Graptolites (New Series) - Part V. - Min. Geol. J. Vict. 1(2), 70-81.

Hede, J. E. 1951: Boring through Middle Ordovician - Upper Cambrian strata in the Fågelsång District, Scania, 1. Succession encounted in the boring. Lunds Univ. Arsskr. (2), 46, No. 7, 1-84.

Hsü, Singwu C. 1936: The Tremadocian in South Anhui. Bull. Geol. Soc. China 15, 105-108.

Hutt, Jana E. 1974: The development of Clonograptus tenellus and Adelograptus hunnebergensis. Lethaia 7, 79-92.

Jackson, D. E. \& Lenz, A. C. 1962: Zonation of Ordovician and Silurian Graptolites of Northern Yukon, Canada. Bull. Am. Ass. Petr. Geol. 46(1), 30-45.

Jackson, D. E. 1973: On the mode of branching in a new species of Clonograptus Palaeontology 16, 707-711.

Kaljo, D. \& Kivimägi, E. 1976: Zonal Stratigraphy of the Estonian Tremadocian In: Kaljo, D. \& Koren, T. (eds.): Graptolites and Stratigraphy. - Academy of Sciences of Estonian SSR, Institute of Geology, Tallinn.

Lapworth, C. 1880: On new British Graptolites. Ann. Mag. Nat. Hist., Ser. 5, vol. 5, 149-176.

Legrand, P. 1960: Sur la presence du genre Clonograptus au Sahara septentrional. Bull. Soc. Geol. France 7(2), 241-243.

Lenz, A. C. \& Pedder, A. E. H. 1972: Lower and Middle Palaeozoic Sediments and Palaeontology of Royal Creek and Peel River, Yukon and Powell Creek, N. W. T. Excursion A-14, 24th Int. Geol. Congr. Montreal.

Lin, Yao-Kun 1981: New materials of Graptodendroids with special reference to the Classification of Graptodendroidea. - Bull. of Nanjing Inst. of Geol. and Pal., Academia Sinica 3, 241-262.

Linnarsson, J. G. O. 1871: Om några försteningar från Sveriges och Norges "Primordialzon". Ofversigt af Kongl. Veten skaps-Akademiens Förhandlingar 6, 789-796.

Linnarsson, J. G. O. 1880: Om försteningarne i de svenska lagren med Peltura och Sphaerophthalmus. Geol. Fören. Förhandl. 5, 132.
Moberg, J. C. 1892: Om skiffern med Clonograptus tenellus, des Fauna och Geologiska Ålder. Sver. Geol. Unders., Ser. C, 125, 87-102.

Moberg, J. C. \& Segerberg, C. O. 1906: Bidrag til kännedomen om Ceratopygeregionen Meddelande frän Lunds Geologiska Fältklub, Ser. B, No. 2.

Monsen, A. 1925: Über eine neue ordovicische GraptolithenFauna. Norsk Geol. Tidsskr. 8, 147-187.

Monsen, A. 1937: Die Graptolithenfauna im Unteren Didymograptusschiefer (Phyllograptusschiefer) Norwegens. Norsk Geol. Tidsskr. 16, 57-263.

$\mathrm{Mu}, \mathrm{A}$. T. 1955: The new materials of the dendroid Graptolites of China. Palaeontologia Sinica, New Series B, 5, 1-62.

Nicholas, T. C. 1915: The Geology of the Tudwal's Peninsula, Caernarvonshire. Quart. J. Geol. Soc. Lond: 71, 83-141.

Nicholson, H. A. 1872: Monograph of the British Graptolitidae. $\mathrm{X}+133$ pp., 74 textfigs., Blackwood \& Sons (Edinburgh, London).

Obut, A. M. \& Sennikov, N. V. 1984: Graptolites and Zonal Subdivisions Lower Ordovician of the Gorny Altai. - In: Kanygin, A. V. (ed.): Lower Ordovician Stratigraphy and Fauna of Mountain Altai. - Academy of Sciences of the USSR, Siberian Branch, Institute of Geology and Geophysics, Transactions 565, 53-106.

Owens, R. M., Fortey, R. A., Cope, J. C. W., Rushton, A. W. A. \& Bassett, M. G. 1982: Tremadoc faunas from the Carmarthen district, South Wales. Geol. Mag. 119, 1-38.

Poulsen, C. 1922: Om Dictyograptusskiffern på Bornholm. Danmarks geologiske Unders $\varnothing$ gelse, IV Rakke, 1, 16.

Poulsen, C. 1937: On the Ordovician Faunas of East Greenland Meddr. Grønland 119, 3.

Rickards, R. B. \& Stait, B. A. 1984: Psigraptus, its classification, evolution and zooid. Alcheringa 8, 101-111.

Rushton, A. W. A. 1981: A polymorphic graptolite from concealed Tremadoc rocks of England Geol. Mag. 118(6), 615-622.

Stubblefield, C. J. 1929: Notes on some early British Graptolites. Geol. Mag. 66, 268-285.

Stubblefield, C. J. \& Bulman, O. M. B. 1927: On the Shineton Shales of the Wrekin district. Quart. J. Geol. Soc. Lond. $83,96-146$.

Thorslund, P. 1937: Notes on the Lower Ordovician of Falbygden. Bull. Geol. Inst. Upp. 27, 145-165.

Tjernvik, T. E. 1958: The Tremadocian beds at Flagabro in South-Eastern Scania (Sweden). Geol. Fören. Förhandl. $80,259-276$.

Törnquist, S. L. 1904: Researches into the Graptolites of the Lower Zones of the Scanian and Vestrogothian PhylloTetragraptus Beds. Lunds Univ. Arsskr. 40, Afdeln. 2, 2.

Ulst, R. 1976: Stratigraphical Significance of the Late Tremadocian and the Arenigian Graptolites of the Middle East Baltic Area. In: Kaljo, D. \& Koren, T. (eds.): Graptolites and Stratigraphy. - Academy of Sciences of the Estonian SSR, Institute of Geology, Tallinn.

Wang Xiao-Feng, Jin Yu-Qin, Wu Zao-Tong, Fu Han-Ying, Li Zuo-Cong \& Ma Guo-Gan 1977: A Handbook of Palaeontology of Central-South China (eds. Wang Xiao-Feng \& Jin Yu-Qin) - Geol. Publ. House, Beijing (in Chinese) 470 pp., 116 plates.

Westergård, A. H. 1909: Studier öfver Dictyograptus-skiffern och dess Gränslager. Medd. Lunds Geol. Fältsklubb, Ser. $B, 4$.

Westergård, A. H. 1922: Sveriges Olenidskiffer. - Sver. Geol. Unders., Ser. Ca, 18.

Westergård, A. H. 1944: Borrningar genom Skånes Alunskiffer 1941-42. Sver. Geol. Unders., Ser. C, 459. 